ISSN: 2578-8760

\title{
Introducing a new international standard ISO/TS 20660: Specification of characteristics and measurement methods for antibacterial silver nanoparticles
}

\author{
Kyung Seuk Song ${ }^{1}$; Somin Lee ${ }^{1}$; Ali Beitollahi²; Jeong Seok Choi ${ }^{3}$;ll Je Yu ${ }^{3 *}$ \\ ${ }^{1}$ Korea Conformity Laboratories, Incheon, Korea \\ ${ }^{2}$ School of Metallurgy and Materials Engineering, Iran University of Science \& Technology, Teheran, Iran \\ ${ }^{3}$ HCTm, Icheon, Korea
}

*Corresponding Author(s): II Je Yu

HCTm, 74, Seoicheon-ro 578 beon-gil Majang-myeon, Icheon, Gyeonggi-do Republic of Korea 17383

Email: u1670916@chollian.net

Received: Feb 27, 2020

Accepted: Apr 29, 2020

Published Online: May 05, 2020

Journal: Journal of Nanomedicine

Publisher: MedDocs Publishers LLC

Online edition: http://meddocsonline.org/

Copyright: (C) Yu IJ (2020). This Article is

distributed under the terms of Creative Commons

Attribution 4.0 International License

Keywords: Nanomaterial; Silver nanoparticles; International standard; Specification; Measurement

\section{Introduction}

Silver nanoparticles (AgNPs) are receiving growing attention due to their antibacterial, chemical, electrical and catalytic properties that have important industrial applications. In particular, AgNPs are increasingly used in consumer products to control the growth of microorganisms on external and internal surfaces. Several consumer product databases now list products containing nanosilver or AgNPs. For example, Nanodata shows 68 AgNP products among 3060 nanoproducts [1] while the Woodrow Wilson consumer product inventory shows

\section{Abstract}

This paper introduces a new international standard [(International Organization for Standardization/Technical Specification (ISO/TS) 20660)]: Specification of characteristics and measurement methods for silver nanoparticles. The new standard provides a guideline of essential and additional characteristics for silver nanoparticles used as antibacterial agents in consumer products, along with the relevant measurement methods. The main rationale behind this standard is to establish relevant and comparable characterization of antibacterial silver nanoparticle products, while boosting consumer trust and confidence.
443 AgNP products (highest subgroup) among 1833 nanoproduct [2]. Although antibacterial nanoproducts containing AgNPs are now widely commercially available, most AgNP-containing products are sold without providing any information on their physicochemical properties and health \& safety data. In most countries, consumer products are not covered by current SDS (Safety Data Sheet) regulations that require disclosure of physicochemical properties and health \& safety data. Most AgNP manufacturers only provide product specifications based on

Cite this article: Song KS, Lee S, Beitollahi A, Choi JS, Yu IJ. Introducing a new international standard ISO/TS 20660: Specification of characteristics and measurement methods for antibacterial silver nanoparticles. J Nanomed. 2020; 3(1): 1019. 
their own practices. Therefore, the new TS attempts to provide standard guidelines for the characterization and measurement of AgNPs in powder or colloidal form that are used as antibacterial agents in consumer products. The new working item proposal for antibacterial AgNPs was already accepted by the ISO Technical Committee (TC) 229 (Nanotechnologies) and technical specification (TS) 20660 was developed by working group 4 (Material specifications) [3]. The new technical specification is intended to help manufacturers provide the appropriate physicochemical characteristics of AgNPs used as antibacterial agents in consumer products, while also ultimately boosting consumer confidence.

\section{Initial market survey of antibacterial AgNP products}

Since this survey is for market survey, we did not use existing organizations created databases such as Woodrow Wilson New nanotechnology consumer products inventory [2], Danish Nanoproduct Inventory [4], or Korean nanofusion product database Nanoin [5]. Additionally, we searched published papers that used silver nanoparticles [6]. Based on internet search using keywords such as antibacterial silver, nanosilver silver nanoparticles, silver nanomaterials, etc, among 834 products, 394 antibacterial products that contained AgNPs smaller than 100 $\mathrm{nm}$ were analyzed as regards the provided specifications. The results are summarized in Table 1. Among the 394 antibacterial AgNP products, 165 included primary particle size information with an average size of $39.8 \mathrm{~nm}$. The average particle size for the $394 \mathrm{AgNP}$ products was $60 \mathrm{~nm} .305 \mathrm{AgNP}$ products included surface charge information, where the average was $-38.8 \mathrm{mV}$, and 66 products included surface area information, where the average was $14.2 \mathrm{~m}^{2} / \mathrm{g}$. 76 products included particle aggregation information, where 67 products claimed no aggregation and 9 products reported aggregation. Consequently, based on this information, the working group formulated essential and additional specification requirements for antibacterial AgNP products.

\section{Scope of technical specification}

The new TS provides guidance for specifying the characteristics and relevant measurement methods for silver nanoparticles in powder or colloidal form that are intended for antibacterial application in consumer products. Particularly, the new TS is intended to help the manufacturer provide the physicochemical characteristics of silver nanoparticles used as antibacterial agents, and does not cover considerations specific to health and safety issues either during manufacturing or use.

\section{Characterization and measurement methods required and} recommended in TS

The new characteristic specification for antibacterial silver nanoparticles consists of two categories: essential and additional characteristics, as described in Tables 2 and 3, respectively. As such, to comply with TS 20660, manufacturers of antibacterial AgNPs will need to provide all the essential characteristics listed in Table 2, and will have the option to provide the additional characteristics listed in Table 3. The essential characteristics are all intrinsic to the material, including the average size and distribution of primary particles, zeta potential, surface area, and total silver content. The TS for AgNPs is applicable to both powder and colloidal forms of AgNPs, yet not aerosol forms. All the characteristics need to be measured using the methods and units prescribed in the TS to allow direct comparison among AgNP products. The additional characteristics cover the hydrodynamic size and silver nanoparticle number concentration.

Table 1: Market survey of antibacterial AgNP products

\begin{tabular}{|c|c|c|c|c|c|}
\hline & Primary particle size $(\mathbf{n m})$ & Particle size $(\mathbf{n m})$ & Surface charge $(\mathbf{m V})$ & Surface area $\left(\mathbf{m}^{2} / \mathbf{g}\right)$ & Aggregation \\
\hline No. of Samples & 165 & 394 & 305 & 66 & 76 \\
\hline Average & 39.8 & 60.0 & -35.8 & 14.3 \\
\hline S.D. & 23.6 & 22.3 & 13.7 & 11.6 & \multirow{2}{*}{ Not Aggregated 67; } \\
\hline Max. & 93.5 & 99.9 & 5.0 & 90.0 & 6.4 \\
\hline Min. & 1.0 & 9.0 & -57.7 & 11.5 & \\
\hline
\end{tabular}

Table 2: Essential characteristics (Adapted from ISO 20660 Table 1 and Annex Table A.1)

\begin{tabular}{|c|c|c|c|c|c|c|}
\hline Characteristics & Units & Reason & $\begin{array}{l}\text { Measurement } \\
\text { method }\end{array}$ & $\begin{array}{l}\text { Applica- } \\
\text { tion form }\end{array}$ & Guidance & Reference \\
\hline $\begin{array}{l}\text { 1) Average size } \\
\text { \& distribution of } \\
\text { primary particles }\end{array}$ & $M$ & $\begin{array}{l}\text { Critical parameter } \\
\text { in assessment } \\
\text { of EHS aspects } \\
\text { of nano-objects } \\
\text { AgNP size is } \\
\text { closely related } \\
\text { with antimicrobial } \\
\text { activity [7] }\end{array}$ & SEM & $\begin{array}{l}\text { Powder or } \\
\text { colloidal }\end{array}$ & $\begin{array}{l}\text { TEM is a microscopy technique in which a beam of } \\
\text { electrons is transmitted through a specimen to form } \\
\text { an image. The specimen is most often an ultrathin } \\
\text { section less than } 100 \mathrm{~nm} \text { thick or a suspension on a } \\
\text { grid. An image is formed from the interaction of the } \\
\text { electrons with the sample as the beam is transmitted } \\
\text { through the specimen. The image is then magnified } \\
\text { and focused onto an imaging device, such as a fluo- } \\
\text { rescent screen, layer of photographic film, or sensor } \\
\text { such as a charge-coupled device. Coupling with EDS } \\
\text { is then widely used for elemental and chemical analy- } \\
\text { ses. }\end{array}$ & $\begin{array}{c}\text { ISO } 16700 \\
{[8]}\end{array}$ \\
\hline
\end{tabular}




\begin{tabular}{|c|c|c|c|c|c|c|}
\hline & & & TEM & $\begin{array}{l}\text { Powder or } \\
\text { colloidal }\end{array}$ & $\begin{array}{l}\text { SEM is a type of electron microscope that produces } \\
\text { images of a sample by scanning the surface with a } \\
\text { focused beam of electrons. The electrons interact } \\
\text { with atoms in the sample, producing various signals } \\
\text { that contain information about the sample's surface } \\
\text { topography and composition. The electron beam is } \\
\text { scanned in a raster scan pattern, and the beam's posi- } \\
\text { tion is combined with the detected signal to produce } \\
\text { an image. SEM can achieve a resolution better than } 1 \\
\text { nanometre. For conventional SEM, the specimens are } \\
\text { observed in a high vacuum, while for environmental } \\
\text { SEM, the specimens can be observed in a low vacuum } \\
\text { or under wet conditions with variable pressure and at } \\
\text { a wide range of cryogenic or elevated temperatures. } \\
\text { Guidelines on the application of this method and } \\
\text { the sample preparation process can be found in ISO } \\
16700 \text { and } 10798 \text {. [Source: ISO } 16700 \text {, modified] }\end{array}$ & $\begin{array}{c}\text { ISO } 10797 \\
{[9]}\end{array}$ \\
\hline 2) Zeta potential & v & $\begin{array}{l}\text { Key factor deter- } \\
\text { mining stability in } \\
\text { suspension with } \\
\text { capping agents } \\
\text { [10] }\end{array}$ & DLS & Colloidal & $\begin{array}{l}\text { Zeta potential is the electrostatic potential at the } \\
\text { slipping plane (which marks the region where the } \\
\text { liquid molecules surrounding the particles first begin } \\
\text { to move with respect to the surface) relative to the } \\
\text { potential in the bulk solution. ISO } 13099-2 \text { provides } \\
\text { methods for measuring the electrophoretic mobil- } \\
\text { ity using optical means and for calculating the zeta } \\
\text { potential. }\end{array}$ & $\begin{array}{l}\text { ISO } \\
13099-2 \\
{[11]}\end{array}$ \\
\hline $\begin{array}{l}\text { 3) Specific surface } \\
\text { area }\end{array}$ & $\mathrm{m}^{2} / \mathrm{kg}$ & $\begin{array}{l}\text { Critical parameter } \\
\text { in chemical and } \\
\text { antibacterial reac- } \\
\text { tion [12-13] }\end{array}$ & & Powder & $\begin{array}{l}\text { A technique based on the model developed by } \\
\text { Brunauer, Emmet and Teller that allows the surface } \\
\text { area of powders to be estimated by the amount of } \\
\text { gas that is adsorbed. Typically, nitrogen or carbon di- } \\
\text { oxide is used, but gases such as krypton or argon may } \\
\text { be used for low surface area materials because of } \\
\text { their sensitivity (mass gain per unit area). The specific } \\
\text { surface area is the ratio of surface area to mass. }\end{array}$ & $\begin{array}{l}\text { ISO } 9277 \\
\text { [14], ISO } \\
\text { 18757 } \\
{[15]}\end{array}$ \\
\hline \multirow{3}{*}{$\begin{array}{l}\text { 4) Total silver } \\
\text { content }\end{array}$} & \multirow{3}{*}{$\begin{array}{c}\mathrm{kg} / \mathrm{kg} \\
\mathrm{or} \\
\mathrm{mol} / \\
\mathrm{mol}\end{array}$} & \multirow{3}{*}{$\begin{array}{l}\text { Critical determi- } \\
\text { nant in assess- } \\
\text { ment of antibac- } \\
\text { terial activity and } \\
\quad \text { purity [16] }\end{array}$} & ICP-MS & $\begin{array}{l}\text { Powder or } \\
\text { colloidal }\end{array}$ & $\begin{array}{l}\text { ICP-MS uses an inductively coupled plasma source to } \\
\text { ionize sample materials for analysis by a mass spec- } \\
\text { trometer. ICP-MS provides accurate and quantitative } \\
\text { determinations of elemental impurities using ICP- } \\
\text { MS. }\end{array}$ & $\begin{array}{c}\text { ISO } \\
17294-1 \\
{[17], \text { ISO }} \\
17294-2 \\
{[18]}\end{array}$ \\
\hline & & & ICP-OES & $\begin{array}{l}\text { Powder or } \\
\text { colloidal }\end{array}$ & $\begin{array}{l}\text { ICP-OES is an analytical technique used for the detec- } \\
\text { tion of trace metals. It is a type of emission spectros- } \\
\text { copy that uses inductively coupled plasma to produce } \\
\text { excited atoms and ions that emit electromagnetic ra- } \\
\text { diation at wave lengths characteristic of a particular } \\
\text { element. It is a flame technique with a flame temper- } \\
\text { ature in a range from } 6000 \text { to } 10000 \mathrm{~K} \text {. The intensity } \\
\text { of this emission is indicative of the concentration of } \\
\text { the element within the sample. }\end{array}$ & $\begin{array}{c}\text { ISO } 11885 \\
\text { [19] }\end{array}$ \\
\hline & & & AAS & $\begin{array}{l}\text { Powder or } \\
\text { colloidal }\end{array}$ & $\begin{array}{l}\text { Any metals in a solution can be readily determined } \\
\text { by flame (direct aspiration) atomic absorption spec- } \\
\text { trophotometry. }\end{array}$ & $\begin{array}{c}\text { ISO } 26845 \\
{[20]}\end{array}$ \\
\hline
\end{tabular}

SEM: scanning electron microscopy; TEM: transmission electron microscopy; DLS: dynamic light scattering; ICP-MS: inductive coupled plasma-mass spectrometry; ICP-OES: inductive coupled plasma-optical emission spectrometry; AAS: atomic absorption spectrometry.

Table 3: Additional characteristics (Adapted from ISO 20660 Table 2 and Annex Table A.2)

\begin{tabular}{|c|c|c|c|c|c|c|}
\hline Characteristics & Units & Reason & $\begin{array}{c}\text { Measurement } \\
\text { method }\end{array}$ & $\begin{array}{c}\text { Application } \\
\text { form }\end{array}$ & Ruidance \\
\hline $\begin{array}{c}\text { 1) Hydrodynamic } \\
\text { size }\end{array}$ & M & $\begin{array}{l}\text { Determines } \\
\text { particle size for } \\
\text { NPs in aqueous } \\
\text { solution }\end{array}$ & DLS & Colloidal & $\begin{array}{l}\text { This method measures the hydrodynamic diam- } \\
\text { eter from Brownian motion. It is applicable to } \\
\text { the measurement of particle diameters greater } \\
\text { than } 3 \mathrm{~nm} \text {, depending on the test material. }\end{array}$ & ISO 22412 [21] \\
\hline
\end{tabular}




\begin{tabular}{|c|c|c|c|c|c|c|}
\hline & & & PTA & Colloidal & $\begin{array}{l}\text { PTA is based on measuring the diffusion move- } \\
\text { ment of particles in a suspension by means of la- } \\
\text { ser illumination, imaging of scattered light, parti- } \\
\text { cle identification and localization, and individual } \\
\text { particle tracking. The hydrodynamic diameter of } \\
\text { the individual particles, droplets or bubbles is } \\
\text { related to Brownian motion parameters via the } \\
\text { Stokes-Einstein equation.] }\end{array}$ & ISO 19430 [22] \\
\hline \multirow[t]{2}{*}{$\begin{array}{l}\text { 2) Silver nano- } \\
\text { particle number } \\
\text { concentration }\end{array}$} & \multirow[t]{2}{*}{$\# / \mathrm{kg}$} & \multirow[t]{2}{*}{$\begin{array}{l}\text { Determines } \\
\text { number-based } \\
\text { particle size } \\
\text { distribution of } \\
\text { nanoparticles } \\
\text { and quantifies } \\
\text { dissolved fraction } \\
\text { of AgNP suspen- } \\
\text { sion }\end{array}$} & spICP-MS & $\begin{array}{c}\text { Powder or } \\
\text { colloidal }\end{array}$ & $\begin{array}{l}\text { spICP-MS is able to detect single nanoparticles } \\
\text { at very low concentrations, and can determine } \\
\text { the size of AgNPs in aqueous suspensions. The } \\
\text { particle number concentrations that can be de- } \\
\text { termined in aqueous suspensions range from } \\
106 \text { particles/L to } 109 \text { particles/L, corresponding } \\
\text { to mass concentrations in the range of approxi- } \\
\text { mately } 1 \mathrm{ng} / \mathrm{l} \text { to } 1000 \mathrm{ng} / \mathrm{l} \text {. The actual numbers } \\
\text { depend on the type of mass spectrometer used } \\
\text { and type of nanoparticle analyzed. spICP-MS can } \\
\text { also determine the ionic concentrations in the } \\
\text { suspension. }\end{array}$ & ISO/TS 19590 [23] \\
\hline & & & SAXS & $\begin{array}{c}\text { Powder or } \\
\text { colloidal }\end{array}$ & $\begin{array}{l}\text { SAXS can determine the NP size distribution, the } \\
\text { size and shape of monodispersed NPs, and the } \\
\text { silver nanoparticle number concentration. }\end{array}$ & [24] \\
\hline
\end{tabular}

DLS: dynamic light scattering; PTA: particle tracking analysis; spICP-MS: single particle inductive coupled plasma-mass spectrometry; SAXS: Small angle X-ray scattering.

\section{Sampling and test report}

The new TS requires representative sampling of the parent population of nanoparticles in a suspended powder form in accordance with ISO 14488 [25] and ISO 14887 [26]. Since many nano-objects are reactive and their physicochemical properties can be affected by the sampling point and storage, the manufacturer and end-producer need to agree on the sampling point and sample storage for result comparability. The test report should contain 1) all details generally necessary to identify the test product (product name, chemical name); 2 ) reference to the new TS; 3) a sample description; 4) the relationship between the sample used for the measurements and the test product to which the characteristics are assigned; 5) the test date, name of the testing laboratory, and a statement on the quality system of the testing laboratory; 6 ) measurement results for the characteristics, including the measurement methods, as in Table 2 and if applicable Table 3; 7) any special information supporting the reliability of the measurement results. If available, the results of any antibacterial performance testing should be provided, along with the documented test procedures.

\section{Antibacterial performance test}

After a great deal of discussion on whether to include antibacterial performance tests in the new TS, the technical committee decided against this antibacterial performance test due to the lack of any current standardization of the antibacterial performance of silver nanoparticles and because antibacterial performance tests are beyond the scope of the new TS. Relevant antibacterial performance tests include ISO/TS 16550 [27] and the performance standards for the antimicrobial disk \& dilution susceptibility test: M2-A9 from the Clinical and Laboratory Standards Institute [28]. The requirements outlined by national pharmacopeia or regulatory bodies can also be consulted and followed if appropriate. Plus, the jurisdictions where the material may ultimately be sold should be considered.

\section{Discussion}

ISO TC 229 (Nanotechnologies) aims to support the sustainable and responsible development and global dissemination of emerging nanotechnologies; to facilitate global trade in nanotechnologies, nanotechnology products, and nanotechnologyenabled systems and products; to support improvement in quality, safety, security, consumer and environmental protection, together with the rational use of natural resources in the context of nanotechnologies; to promote good practice in the production, use, and disposal of nanomaterials, nanotechnology products, and nanotechnology-enabled systems and products. Initially, the TC focused on the terminology and nomenclature, metrology and test methods, and health, safety, and the environment. The working group for material specification (WG 4) was created in 2008 and published several standards, including Materials specifications - Guidance on specifying nano-objects (ISO 12805) [26], Clay nanomaterials - Part 1: Specification of characteristics and measurement methods for layered clay nanomaterials (ISO/TS 21236-1) [27], and Magnetic nanomaterials - Part 1: Specification of characteristics and measurements for magnetic nanosuspensions (ISO/TS 19807-1) [28]. Although antibacterial AgNP products are already produced and used worldwide, a standardized product specification is not yet available. This lack of consensus on how manufacturers of antibacterial products prepare product specifications for the market also affects consumer confidence in antibacterial AgNP products. Therefore, the new TS for antibacterial AgNP products guides manufacturers on which essential and additional characteristics to include in their product specifications. Furthermore, the new TS prescribes particular measurement methods to provide comparable specification data among products, thereby ultimately helping to boost consumer confidence in AgNP-applied nanoproducts. In addition to providing essential and additional specification requirements for antibacterial AgNP, this TS also provide characterization methods for the specification requirements to have consistency on specification data among the 
products. The published standard will influence on the future market for AgNP applied nanoproducts and will build consumer trust as well as the facilitation of communication between seller and buyer in more details by utilizing this standard to fill the gap of reliable measurement protocol or methods.

Although the working group initially considered the inclusion of antibacterial performance tests in the new TS, this was dropped due to the current lack of any standardization of antibacterial AgNP performance and because this issue was determined beyond the scope of the working group. Finally, it is hoped that the new technical specification will encourage the commercialization of nanotechnologies by promoting good practice in production and building consumer confidence.

\section{Acknowledgements}

This study was supported by the Global Top EnvironmentTechnology Development project (No. 2018001860004) funded by the Ministry of Environment.

\section{References}

1. Nanodata. Nanotechnology Knowledge Base. https://nanodata. echa.europa.eu/ accessed at 5/20/2019.

2. Woodrow Wilson International Center for Scholars, New nano-technology consumer products inventory. https://www. wilsoncenter.org/article/new-nanotechnology-consumer-products-inventory, accessed at 11/11/2019.

3. ISO/TS 20660. Specification of characteristics and measurement methods for Antibacterial silver nanoparticles, ISO, Geneva. 2019.

4. Danish Nanoproduct Registry. https://indberet.virk.dk/ accessed at $6 / 25 / 2018$.

5. Nanoin. www.nanoin.org, accessed at 4/30/2018

6. S2 Nano. http://portal.s2nano.org/, accessed at 5/5/2018

7. Martinez-Castanon GA, Nino-Martinez N, Martinez-Gutierrez F. Synthesis and antibacterial activity of silver nanoparticles with different sizes, Journal of Nanoparticle Research.2008; 10: 13431348 .

8. ISO 16700 , Microbeam analysis - Scanning electron microscopy - Guidelines for calibrating image magnification, ISO, Geneva. 2016.

9. ISO/TS 10797, Nanotechnologies - Characterization of singlewall carbon nanotubes using transmission electron microscopy, ISO, Geneva. 2012.

10. Gholami A, Ghoshoon MB, Ghafari P. The effect of different positively charged silver nanoparticles against bacteria, fungi and mammalian cell line. Trends in pharmaceutical science.2017; 3: 135-142.

11. ISO 13099-2, Colloidal systems - Methods for zeta-potential determination - Part 2: Optical methods. ISO, Geneva. 2012.

12. Khaydarov RR, Khaydarov RA, Estrin Y. Nanomaterials: Risk and Benefits, Springer, Netherlands. 2009; 287-299.

13. Pal S, Tak YK, Song JM. Does the antibacterial activity of silver nanoparticles depend on the shape of the nanoparticle? A study of the Gram-negative bacterium Escherichia coli. Applied and Environmental Microbiology.2007; 73: 1712-1720.

14. ISO 9277, Determination of the specific surface area of solids by gas adsorption - BET method. ISO, Geneva. 2010. 2003.
15. ISO 18757, Fine ceramics (advanced ceramics, advanced technical ceramics) - Determination of specific surface area of ceramic powders by gas adsorption using the BET method. ISO, Geneva. 2003.

16. Sotiriou GA, Pratsinis SE. Engineering nanosilver as an antibacterial, biosensor and bioimaging material, Current Opinion in Chemical Engineering. 2011; 1: 3-10.

17. ISO 17294-1, Water quality - Application of inductively coupled plasma mass spectrometry (ICP-MS) - Part 1: General guidelines. ISO, Geneva, 2004

18. ISO 17294-2, Water quality - Application of inductively coupled plasma mass spectrometry (ICP-MS) - Part 2: Determination of selected elements including uranium isotopes. ISO, Geneva. 2016.

19. ISO 11885, Water quality - Determination of selected elements by inductively coupled plasma optical emission spectrometry (ICP-OES). ISO. Geneva. 2007.

20. ISO 26845, Chemical analysis of refractories - General requirements for wet chemical analysis, atomic absorption spectrometry (AAS) and inductively coupled plasma atomic emission spectrometry (ICP-AES) methods. ISO Geneva. 2008.

21. ISO 22412, Particle size analysis - Dynamic light scattering (DLS). ISO, Geneva, 2016.

22. ISO 19430, Particle size analysis - Particle tracking analysis (PTA) method. ISO, Geneva. 2016.

23. ISO/TS 19590, Nanotechnologies - Size distribution and concentration of inorganic nanoparticles in aqueous media via single particle inductively coupled plasma mass spectrometry. ISO, Geneva. 2017.

24. Pauw R, Kästner C, Thünemann A. Nanoparticle size distribution quantification: results of a small-angle X-ray scattering inter-laboratory comparison. Journal of applied crystallography. 2017; 50: $1280-1288$.

25. ISO 14488, Particulate materials - Sampling and sample splitting for the determination of particulate properties. ISO, Geneva. 2007.

26. ISO 14887, Sample preparation - Dispersing procedures for powders in liquids. ISO, Geneva. 2000.

27. ISO/TS 16550, Nanotechnologies - Determination of silver nanoparticles potency by release of muramic acid from Staphylococcus aureus. ISO, Geneva. 2014.

28. Performance standards for antimicrobial disk and dilution susceptibility test: M2-A9 Vol.26 No.1, Clinical and laboratory standards institute.

29. ISO/TS 12805, Nanotechnologies - Materials specifications Guidance on specifying nano-objects. ISO, Geneva. 2011.

30. ISO/TS 21236-1, Nanotechnologies-Clay nanomaterials-Part 1: Specification of characteristics and measurement methods for layered clay nanomaterials. ISO, Geneva. 2019

31. ISO/TS 19807-1 Part 1: Specification of characteristics and measurements for magnetic nanosuspensions. ISO, Geneva. 2019. 